\title{
Pseudovibrio japonicus sp. nov., isolated from coastal seawater in Japan
}

\author{
Shoichi Hosoya and Akira Yokota
}

\author{
Correspondence \\ Shoichi Hosoya \\ shouichi.hosoya@mbio.jp
}

\author{
Institute of Molecular and Cellular Biosciences, The University of Tokyo, Yayoi 1-1-1, Bunkyo-ku, \\ Tokyo 113-0032, Japan
}

\begin{abstract}
A Gram-negative, motile, rod-shaped bacterium $\left(\mathrm{WSF}^{\top}\right.$ ) was isolated from coastal seawater of the Boso Peninsula in Japan. Phylogenetic analysis based on 16S rRNA gene sequences showed that strain $\mathrm{WSF}^{\top}{ }^{\top}$ represented a separate lineage within the genus Pseudovibrio. The DNA

$\mathrm{G}+\mathrm{C}$ content of strain $\mathrm{WSF}^{\top}$ was $51.7 \mathrm{~mol} \%$. DNA-DNA hybridization values between strain WSF $2^{\top}$ and the type strains of Pseudovibrio species were significantly lower than those accepted as the phylogenetic definition of a species. Furthermore, some biochemical characteristics indicated that strain WSF2 ${ }^{\top}$ differed from other Pseudovibrio species. Based on these characteristics, it is proposed that the isolate represents a novel species, Pseudovibrio japonicus sp. nov. The type strain is $\mathrm{WSF}^{\top}\left(=\mathrm{IAM} 15442^{\top}=\mathrm{NCIMB} 14279^{\top}=\mathrm{KCTC}^{12861^{\top}}\right)$.
\end{abstract}

The genus Pseudovibrio was proposed by Shieh et al. (2004) and originally contained one species, Pseudovibrio denitrificans, isolated from seawater in Taiwan. A second species, Pseudovibrio ascidiaceicola, isolated from a sea squirt, was described recently by Fukunaga et al. (2006). This genus contains halophilic, facultatively anaerobic bacteria that are motile by means of one to several lateral or subpolar flagella. Phylogenetic analyses based on $16 \mathrm{~S}$ rRNA gene sequences have shown that the genus Pseudovibrio falls within the Alphaproteobacteria and is closely related to the genera Pannonibacter, Roseibium and Stappia (Shieh et al., 2004; Fukunaga et al., 2006).

In this study, the taxonomic position of strain $\mathrm{WSF}^{\mathrm{T}}$, which was isolated from surface seawater off the coastline of Nojimazaki in the Boso Peninsula, Chiba Prefecture, Japan, was examined. A seawater sample $(0.05 \mathrm{ml})$ was spread onto a plate containing modified SP5 agar $[0.5 \times$ artificial seawater (ASW; $1.5 \% \mathrm{NaCl}, 0.035 \% \mathrm{KCl}$, $0.54 \% \mathrm{MgCl}_{2} \cdot 6 \mathrm{H}_{2} \mathrm{O}, 0.27 \% \mathrm{MgSO}_{4} \cdot 7 \mathrm{H}_{2} \mathrm{O}$ and $0.05 \%$ $\mathrm{CaCl}_{2} \cdot 2 \mathrm{H}_{2} \mathrm{O}$ ), $0.9 \%$ casitone, $0.1 \%$ extract bonito (Wako Pure Chemical Industries) and $1.5 \%$ agar] and incubated at $25{ }^{\circ} \mathrm{C}$ for a week. Strain WSF2 ${ }^{\mathrm{T}}$ was isolated using the dilution-plating technique at $25^{\circ} \mathrm{C}$. This isolate was maintained at $25{ }^{\circ} \mathrm{C}$ on marine agar 2216 (MA; Difco).

The 16S rRNA gene sequence was analysed as described by Hosoya et al. (2006). Sequences were edited and assembled using the program BIOEDIT (Hall, 1999). The most closely related sequences were found using the program BLAST of

Abbreviation: ASW, artificial seawater.

The GenBank/EMBL/DDBJ accession number for the 16S rRNA gene

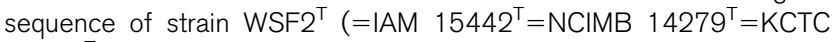
$\left.12861^{\top}\right)$ is $A B 246748$. the GenBank database (Altschul et al., 1990). Multiple alignments were performed using the program CLUSTAL_X (version 1.83; Thompson et al., 1997). Nucleotide substitution rates ( $K_{\text {nuc }}$; Kimura, 1980) were determined. Phylogenetic trees were constructed using the neighbourjoining method (Saitou \& Nei, 1987) with CLUSTAL_X and the maximum-parsimony method (Fitch, 1971) with the software MEGA3 (Kumar et al., 2004). Alignment gaps and unidentified base positions were not taken into consideration in the calculation. The topology of the phylogenetic trees was evaluated by performing a bootstrap analysis with 1000 bootstrapped trials. The dendrogram obtained by maximum-parsimony analysis showed essentially the same topography as data determined by neighbour-joining (data not shown). Phylogenetic analysis based on 16S rRNA gene sequences showed that strain $\mathrm{WSF}^{\mathrm{T}}$ falls into the genus Pseudovibrio (Fig. 1); 16S rRNA gene sequence similarity values with the type strains of $P$. ascidiaceicola and $P$. denitrificans were 98.9 and $98.3 \%$, respectively. For analysis of genetic relatedness, DNA-DNA hybridization was carried out at $45{ }^{\circ} \mathrm{C}$ for $4 \mathrm{~h}$ and measured fluorometrically using the method of Ezaki et al. (1989). Strain WSF2 ${ }^{\mathrm{T}}$ showed relatively low DNA-DNA relatedness values to $P$. ascidiaceicola IAM $15084^{\mathrm{T}}(14.1-32.0 \%)$ and $P$. denitrificans JCM $12308^{\mathrm{T}}(34.9-35.4 \%)$. These values are significantly lower than that accepted as the phylogenetic definition of a species (Wayne et al., 1987).

For determination of the $\mathrm{G}+\mathrm{C}$ content, DNA was extracted by the method of Saito \& Miura (1963) and $\mathrm{G}+\mathrm{C}$ content was determined by the method of Mesbah et al. (1989). The $\mathrm{G}+\mathrm{C}$ content of strain $\mathrm{WSF}^{\mathrm{T}}$ was $51.7 \mathrm{~mol} \%$; those of the reference strains $P$. ascidiaceicola IAM $15084^{\mathrm{T}}$ and P. denitrificans JCM $12308^{\mathrm{T}}$ were 52.1 and $51.9 \mathrm{~mol} \%$, respectively. 


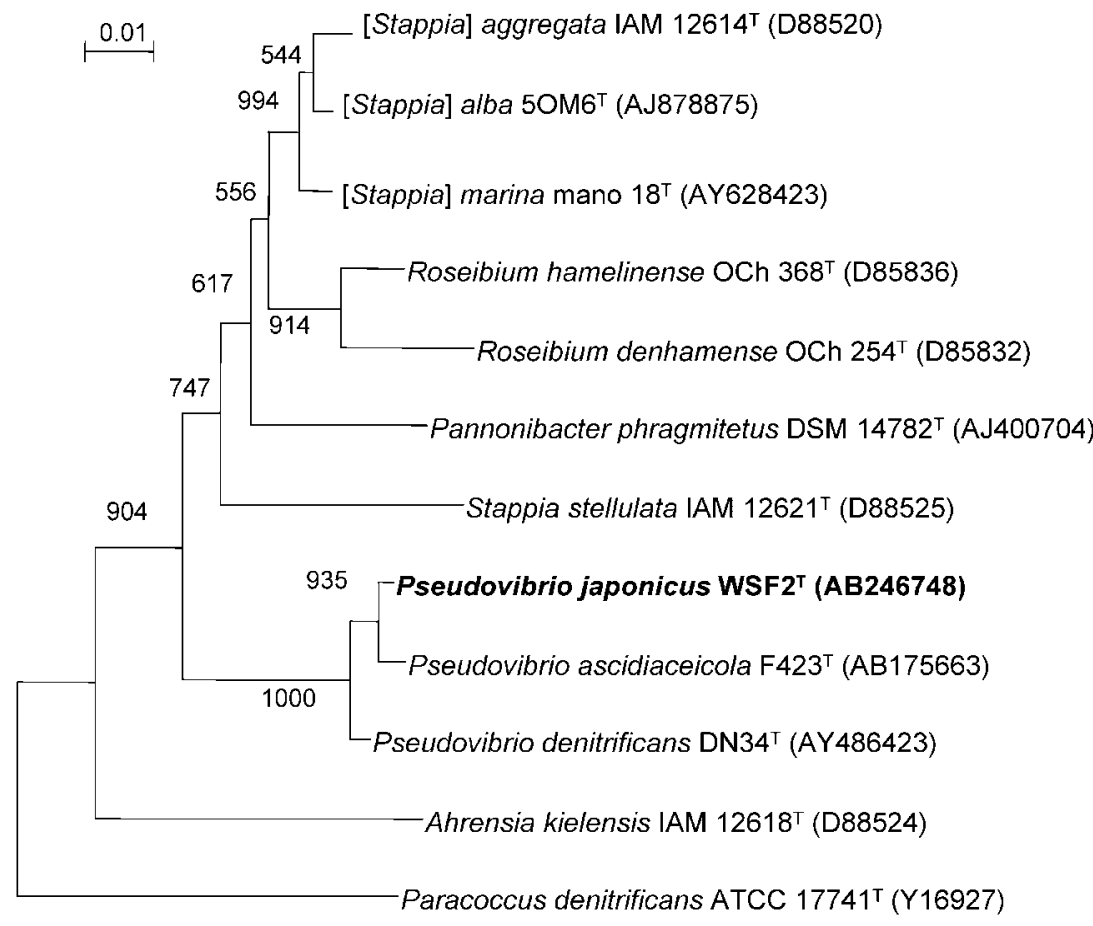

Fig. 1. Neighbour-joining phylogenetic tree of Pseudovibrio japonicus and other related genera of Alphaproteobacteria based on 16S rRNA gene sequence analysis. Bootstrap values greater than 500 are given at branch points. Bar, $0.01 K_{\text {nuc }}$

Phenotypic characteristics were determined as follows. Cells were grown for $48 \mathrm{~h}$ at $25{ }^{\circ} \mathrm{C}$ on MA and observed by TEM after negative staining with uranyl acetate. Gram staining was performed using the Hucker staining method described by Smibert \& Krieg (1994). Spore staining was performed using the Schaeffer \& Fulton staining method described by Barrow \& Feltham (1993). Salt tolerance was tested on R2A agar (Difco) supplemented with 0-10\% $\mathrm{NaCl}$. Growth at different temperatures $\left(8-37{ }^{\circ} \mathrm{C}\right)$ and $\mathrm{pH}$ values (range $\mathrm{pH}$ 5.0-9.5), and cytochrome oxidase and catalase activities were determined by methods described previously (Hosoya et al., 2006). Hydrolysis of DNA was determined on DNA agar (Nissui) supplemented with $0.5 \times$ ASW by the discoloration of toluidine blue. Degradation of starch was tested on SP5 medium containing $0.2 \%$ soluble starch by the method of Smibert \& Krieg (1994). Acid production from carbon sources was tested on Leifson modified $\mathrm{O} / \mathrm{F}$ medium incubated at $25{ }^{\circ} \mathrm{C}$ for a week by the method of Smibert \& Krieg (1994). Hydrolysis of Tweens (20,40, 60 and 80) was tested on modified Tween 80 medium [containing $0.1 \%$ peptone, $0.5 \times$ ASW, $1 \%(\mathrm{v} / \mathrm{v})$ Tweens and $2 \%$ agar] by the method of Barrow \& Feltham (1993). Degradation of L-tyrosine was tested on nutrient agar (Difco) containing $0.5 \%$ L-tyrosine supplemented with $0.5 \times$ ASW by the method of Barrow \& Feltham (1993). Growth under anaerobic conditions was tested on MA at $25{ }^{\circ} \mathrm{C}$ for a week in an AnaeroPack (Mitsubishi Gas Chemical). Tests with the commercial systems API ZYM and API 20E (bioMérieux) were generally performed according to the manufacturer's instructions. Cells for inoculation to the API test strips were suspended in $0.5 \times$ ASW. The API ZYM tests were read after $4 \mathrm{~h}$ incubation at $25{ }^{\circ} \mathrm{C}$ and API 20E tests were read after $48 \mathrm{~h}$ at $25{ }^{\circ} \mathrm{C}$. API 20E data pertaining to acid production from sugars were not utilized because reactions were weak. For analysis of cellular fatty acids, cells were grown for $48 \mathrm{~h}$ at $25{ }^{\circ} \mathrm{C}$ on trypticase soy agar (BBL) supplemented with $0.5 \times$ ASW and then analysed by using the GC-based Microbial Identification system (MIDI).

Strain WSF $2^{\mathrm{T}}$ was a Gram-negative, facultatively anaerobic, non-sporulating bacterium. It formed beige colonies. Cells were approximately $2.0-4.0 \mu \mathrm{m}$ long by $0.8-1.0 \mu \mathrm{m}$ wide and motile by lateral or subpolar flagella (Fig. 2). Phenotypic characteristics are given in the species description. Phenotypically, strain WSF $2^{\mathrm{T}}, P$. ascidiaceicola IAM $15084^{\mathrm{T}}$ and $P$. denitrificans JCM $12308^{\mathrm{T}}$ differed from each other in their chymotrypsin and $\alpha$-glucosidase activities and their ability to produce acid from arabinose, galactose, inositol, maltose, raffinose and trehalose. The major cellular fatty acid of strain WSF2 ${ }^{\mathrm{T}}, P$. ascidiaceicola IAM $15084^{\mathrm{T}}$ and $P$. denitrificans JCM $12308^{\mathrm{T}}$ was $18: 1 \omega 7 c$, although present in different amounts, but strain $\mathrm{WSF}^{\mathrm{T}}$ also contained 16:0 3-OH, which was not detected in $P$. ascidiaceicola or $P$. denitrificans (Table 1).

On the basis of DNA-DNA hybridization, phylogenetic analysis and phenotypic characteristics, strain $\mathrm{WSF}^{\mathrm{T}}$ is proposed as a novel species of the genus Pseudovibrio, Pseudovibrio japonicus sp. nov.

\section{Description of Pseudovibrio japonicus sp. nov.}

Pseudovibrio japonicus (ja.po'ni.cus. N.L. masc. adj. japonicus pertaining to Japan, where the isolate originated).

Cells are Gram-negative, facultatively anaerobic, rodshaped, approximately $2.0-4.0 \times 0.8-1.0 \mu \mathrm{m}$. Motile by 




Fig. 2. TEM of a negatively stained cell of strain $\mathrm{WSF}^{\top}{ }^{\top}$. Bar, $1 \mu \mathrm{m}$.

lateral or subpolar flagella. Cytochrome oxidase- and catalase-positive. Optimal growth temperature is 25$30{ }^{\circ} \mathrm{C}$; grows at $15{ }^{\circ} \mathrm{C}$, but not at 8 or $35^{\circ} \mathrm{C}$. The $\mathrm{pH}$ range for growth is 6.0-9.0. Growth occurs at $\mathrm{NaCl}$ concentrations of $1-6 \%$; no growth occurs at $7 \% \mathrm{NaCl}$. No growth occurs in the absence of $\mathrm{NaCl}$. Positive for alkaline phosphatase, esterase (C4), esterase lipase (C8), leucine arylamidase, valine arylamidase, trypsin, acid phosphatase, naphthol-AS-BI-phosphohydrolase and $\beta$ galactosidase. Positive for degradation of DNA, gelatin

Table 1. Fatty acid profiles of Pseudovibrio species

Strains: 1 , P. japonicus strain WSF2 ${ }^{\mathrm{T}} ; 2$, P. ascidiaceicola IAM $15084^{\mathrm{T}}$; 3, P. denitrificans JCM $12308^{\mathrm{T}}$. Values are percentages $(\mathrm{w} / \mathrm{w})$ of total fatty acids. - , Not detected or trace amount $(<1.0 \%)$.

\begin{tabular}{|lccc|}
\hline Fatty acid & $\mathbf{1}$ & $\mathbf{2}$ & $\mathbf{3}$ \\
\hline $16: 0$ & 8.1 & 1.3 & 7.1 \\
$16: 0$ 3-OH & 2.0 & - & - \\
$17: 0$ & - & - & 1.0 \\
$18: 1 \omega 7 c$ & 80.2 & 74.6 & 83.0 \\
$18: 0$ & 2.0 & 8.8 & 1.7 \\
$19: 0$ cyclo $\omega 8 c$ & - & 3.9 & - \\
$18: 0$ 3-OH & - & 2.3 & 1.4 \\
Summed feature $2^{*}$ & 2.3 & 2.2 & 1.9 \\
Summed feature $3 \dagger$ & 1.9 & 2.2 & 1.3 \\
\hline
\end{tabular}

${ }^{*}$ Summed feature 2 contains 14:0 3-OH and/or 16:1 iso I. $\dagger$ Summed feature 3 contains $15: 0$ iso $2-\mathrm{OH}$ and/or $16: 1 \omega 7 c$. and Tweens (20, 40, 60 and 80). Indole is produced from tryptophan. Tyrosine is degraded. Nitrate is reduced to nitrogen (API 20E). Acid is produced by fermentation from cellobiose, fructose, glucose, mannose, sucrose and xylose. Acid is produced by oxidation from glycerol. Does not decompose citrate, starch or urea. Does not produce acetoin or $\mathrm{H}_{2} \mathrm{~S}$. Negative for arginine dihydrolase, lysine decarboxylase, ornithine decarboxylase, lipase (C4), cystine arylamidase, chymotrypsin, $\alpha$-galactosidase, $\beta$-glucuronidase, $\alpha$-glucosidase, $\beta$-glucosidase, $N$-acetyl- $\beta$-glucosamidase, $\alpha$-mannosidase and $\alpha$-fucosidase. Does not produce acid from arabinose, dulcitol, galactose, inositol, lactose, maltose, mannitol, raffinose, rhamnose, sorbitol or trehalose. The major fatty acid is $18: 1 \omega 7 c$. The DNA G+C content of the type strain is $51.7 \mathrm{~mol} \%$.

The type strain is $\mathrm{WSF}^{\mathrm{T}} \quad\left(=\mathrm{IAM} \quad 15442^{\mathrm{T}}=\mathrm{NCIMB}\right.$ $14279^{\mathrm{T}}=$ KCTC $12861^{\mathrm{T}}$ ), isolated from coastal seawater of the Boso Peninsula in Japan.

\section{References}

Altschul, S. F., Gish, W., Miller, W., Myers, E. W. \& Lipman, D. J. (1990). Basic local alignment search tool. J Mol Biol 215, 403-410.

Barrow, G. I. \& Feltham, R. K. A. (1993). Cowan and Steel's Manual for the Identification of Medical Bacteria, 3rd edn. Cambridge: Cambridge University Press.

Ezaki, T., Hashimoto, Y. \& Yabuuchi, E. (1989). Fluorometric deoxyribonucleic acid-deoxyribonucleic acid hybridization in microdilution wells as an alternative to membrane filter hybridization in which radioisotopes are used to determine genetic relatedness among bacterial strains. Int J Syst Bacteriol 39, 224-229.

Fitch, W. M. (1971). Toward defining the course of evolution: minimum change for a specific tree topology. Syst Zool 20, 406-416.

Fukunaga, Y., Kurahashi, M., Tanaka, K., Yanagi, K., Yokota, A. \& Harayama, S. (2006). Pseudovibrio ascidiaceicola sp. nov., isolated from ascidians (sea squirts). Int J Syst Evol Microbiol 56, 343-347.

Hall, T. A. (1999). BIOEDIT: a user-friendly biological sequence alignment editor and analysis program for Windows 95/98/NT. Nucleic Acids Symp Ser 41, 95-98.

Hosoya, S., Arunpairojana, V., Suwannachart, C., Kanjana-Opas, A. \& Yokota, A. (2006). Aureispira marina gen. nov., sp. nov., a gliding, arachidonic acid-containing bacterium isolated from the southern coastline of Thailand. Int J Syst Evol Microbiol 56, 2931-2935.

Kimura, M. (1980). A simple method for estimating evolutionary rates of base substitutions through comparative studies of nucleotide sequences. J Mol Evol 16, 111-120.

Kumar, S., Tamura, K. \& Nei, M. (2004). MEGA3: integrated software for molecular evolutionary genetics analysis and sequence alignment. Brief Bioinform 5, 150-163.

Mesbah, M., Premachandran, U. \& Whitman, W. B. (1989). Precise measurement of the $\mathrm{G}+\mathrm{C}$ content of deoxyribonucleic acid by highperformance liquid chromatography. Int J Syst Bacteriol 39, 159-167.

Saito, H. \& Miura, K. (1963). Preparation of transforming deoxyribonucleic acid by phenol treatment. Biochim Biophys Acta 72, 619-629.

Saitou, N. \& Nei, M. (1987). The neighbor-joining method: a new method for reconstructing phylogenetic trees. Mol Biol Evol 4, 406425.

Shieh, W. Y., Lin, Y.-T. \& Jean, W. D. (2004). Pseudovibrio denitrificans gen. nov., sp. nov., a marine, facultatively anaerobic, fermentative 
bacterium capable of denitrification. Int J Syst Evol Microbiol 54, 2307-2312.

Smibert, R. M. \& Krieg, N. R. (1994). Phenotypic characterization. In Manual of Method for General and Molecular Bacteriology, pp. 607654. Edited by P. Gerhardt, R. G. E. Murray, W. A. Wood \& N. R. Krieg. Washington, DC: American Society for Microbiology.

Thompson, J. D., Gibson, T. J., Plewniak, F., Jeanmougin, F. \& Higgins, D. G. (1997). The CLUSTAL_X windows interface: flexible strategies for multiple sequence alignment aided by quality analysis tools. Nucleic Acids Res 25, 4876-4882.

Wayne, L. G., Brenner, D. J., Colwell, R. R., Grimont, P. A. D., Kandler, O., Krichevsky, M. I., Moore, L. H., Moore, W. E. C., Murray, R. G. E. \& other authors (1987). International Committee on Systematic Bacteriology. Report of the ad hoc committee on reconciliation of approaches to bacterial systematics. Int $J$ Syst Bacteriol 37, 463-464. 